\title{
Het tijdschrift Mesures, een literair netwerk van de jaren dertig
}

\author{
SOPHIE LEVIE
}

\section{L'ARCHE? LETTRES? MÉTAMORPHOSE?}

In de zomer en de herfst van 1934 polst Jean Paulhan een aantal bevriende auteurs van wie hij verwacht dat zij belangstelling hebben om mee te werken aan een nieuw op te richten tijdschrift. Zelf is Paulhan sinds 1925 hoofdredacteur van de Nouvelle Revue Française, een functie die hij zeer zorgvuldig en met een grote alertheid vervult. ${ }^{1}$ Doordat hij deze positie bekleedt, kan hij niet al te veel op de voorgrond treden bij de redactievoering van een ander, wellicht concurrerend tijdschrift, maar is hij wel uitstekend op de hoogte van de plannen en de projecten van een groot aantal Franse auteurs. Van deze kennis profiteren al sinds 1920 de vele tijdschriften waarmee hij in nauw contact staat (Commerce bijvoorbeeld) of die met hem wat lossere banden onderhouden (Littérature, Bifur en andere avantgarde-bladen). Hoe goed hij het literaire leven in Parijs kent, blijkt uit zijn gepubliceerde en ongepubliceerde correspondentie met talloze Franse en buitenlandse schrijvers. ${ }^{2}$

Giuseppe Ungaretti is de eerste die Paulhan zijn medewerking toezegt. Paulhan wil hem graag in het redactiecomité hebben en in augustus 1934 antwoordt Ungaretti: 'C'est bon pour la revue que Church veut fonder. Le seul titre supportable parmi ceux que tu m'indiques est L'Arche.'

Aan André Gide schrijft Paulhan begin september van hetzelfde jaar:

Il doit paraître, à partir du $1^{\text {er }}$ Janvier 1935, une revue qui sera de l'ordre

(à peu près) de Commerce:

1. donnant 100 frs de la page

2. trimestrielle

3. ayant (il me semble) bon goût 
4. avec des poèmes de toutes langues, et quelques vieux textes.

C'est en principe, Groethuysen, Ungaretti, Michaux, Church et moi qui nous en occuperions: et je n'ai besoin de vous dire combien nous voudrions voir votre nom à son premier sommaire. ${ }^{4}$

Ook Marcel Jouhandeau, Francis Ponge en René Daumal worden in een vroeg stadium van de plannen op de hoogte gesteld: zij zullen allen in de eerste jaargang van het nieuwe blad publiceren. ${ }^{5}$

Aan Valery Larbaud vraagt Paulhan veel meer dan een tekst. In september 1934 laat hij Larbaud weten dat er een nieuw tijdschrift bijkomt, Lettres, dat een beroep op hem hoopt te kunnen doen voor een bijdrage in de vorm van een verhaal of een essay. Dat is echter niet het enige. Ook als raadgever en om onbekende auteurs te signaleren, heeft het tijdschrift hem nodig. Een maand later komt Paulhan op het onderwerp terug. Hij somt op wie er aan het eerste nummer zullen bijdragen (Claudel, Jouhandeau, Fargue, Audiberti) en verzucht:

Combien je voudrais que Valery Larbaud n'en fût pas absent. Les étrangers seront: Musil (avec un fragment de L'Homme sans-caractères: c'est, depuis Kafka, le plus grand écrivain qui ait vécu en Allemagne); Pasternak, Dorothy Richardson (avec une page 'sur la ponctuation').

Nous voudrions aussi donner une lettre inédite, et un poème, de G. M. Hopkins. Accepteriez-vous de les traduire? Je vous en prie?

Gide doit nous donner la traduction de La Demoiselle de village, de Pouchkine.

Non ce n'est pas chez Gaston, mais chez Adrienne Monnier que parấtra Lettres. C'est Henry Church qui le fonde (ne l'avez-vous pas connu à la Phalange?). Et le comité, je pense (mais il ne s'agit pas tout à fait d'un comité, plutôt d'amis, ou de secrétaires de bonne volonté) comprendrait Ungaretti, Groethuysen, Michaux et moi. ${ }^{6}$

Hij leidt zijn poging om Larbaud over te halen strategisch in: 'Il me semble que Lettres (ou Mesure, ou Métamorphose) sera assez beau, et presque digne de Commerce.' Maar hoe aantrekkelijk Paulhan het ook voorstelt, Larbaud geeft nul op het rekest. Hij weigert iedere medewerking aan het tijdschrift omdat 


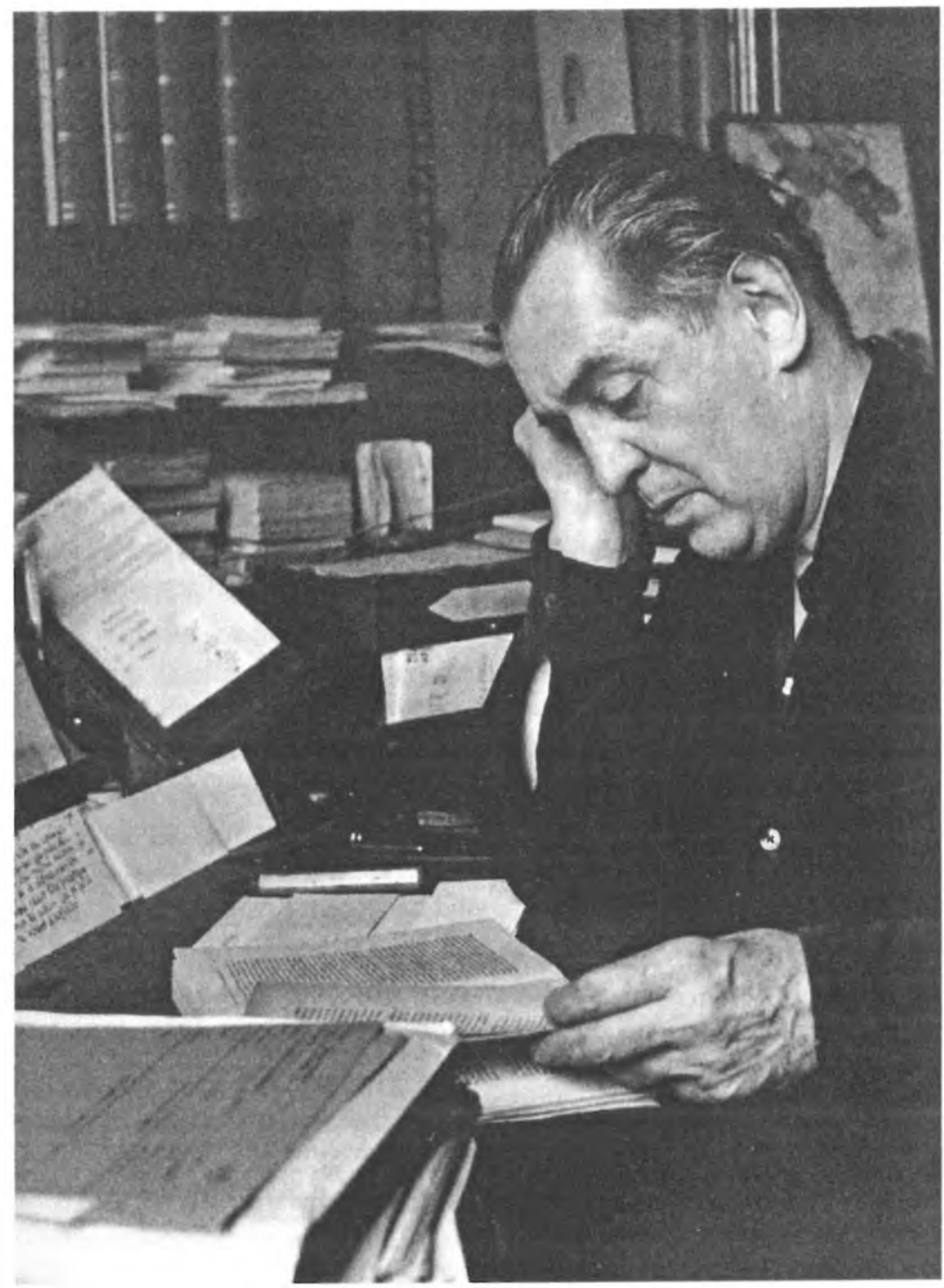

Jean Paulhan (foto Gisèle Freund) 
Adrienne Monnier, met wie hij sinds 1924 is gebrouilleerd, de administratie op zich zal nemen. ${ }^{7}$

HENRY CHURCH, DIRECTEUR VAN HET NIEUWE TIJDSCHRIFT

Henry Church (1880-1947), een Amerikaan uit Brooklyn wiens familie een fortuin had verdiend met de uitvinding en productie van natriumwaterstofcarbonaat, verbleef al sinds de eeuwwisseling in Europa. Verwijzingen naar zijn aanwezigheid in het artistieke leven in Parijs tussen de twee wereldoorlogen zijn in verschillende mémoires en briefwisselingen uit onder andere de kringen rond Adrienne Monnier en Sylvia Beach te vinden. Een volledig en betrouwbaar beeld van zijn contacten en activiteiten is echter niet te geven, omdat het onderzoek dat hiervoor nodig is tot op heden, ondanks een zoektocht vanuit de Widener Library (Harvard University), zonder resultaat is gebleven. Vast staat dat hij zelf ook schreef (gedichten, verhalen en toneel) en vertaalde (Richard III van Shakespeare en stukken van G.K. Chesterton en Georg Kaiser), dat hij kunst verzamelde, piano speelde, en dat hij de oprichter en mecenas van Mesures is geweest. ${ }^{8}$

De financiering van het tijdschrift was zijn zaak, maar de inhoudelijke kant was dat evenzeer, naar blijkt uit zijn brieven aan Paulhan. In een brief gedateerd 25 augustus 1934 doet Church Paulhan een aantal suggesties met betrekking tot de naam en de teksten voor het eerste nummer, evenals voor het uiterlijk en de omvang van het nieuwe tijdschrift. Hij geeft tevens aan hoe de redactie naar zijn idee moet opereren om niet in conflict te komen met gerenommeerde auteurs die aan het blad willen bijdragen, terwijl de redactie hun teksten niet geschikt vindt. Zijn voorstel is een fictieve chef in het leven te roepen die verantwoordelijk is voor de afwijzingen zodat Paulhan geen problemen krijgt met zijn NRF-auteurs. De toon van de brief is eerder wat aarzelend dan autoritair: Church lijkt te erkennen dat Paulhan de man met ervaring was in tijdschriftzaken, en hijzelf de dilettant. ${ }^{9}$

Tot het eind van het jaar blijft de kwestie van de naam een rol spelen in Church' brieven. Hij schrijft enigszins geprikkeld: 'Je ne vise nullement à faire de LETTRES une revue statique; je vous ai proposé de l'appeler DEVENIR.' En een andere keer: 
Question titre, que diriez-vous de caracteres. Pour mesures mon impression est la même. Le lecteur penserait à la mesure, aux mesures que nous voulons prendre pour imposer notre esthétique, à une tendance. C'est ce que je veux éviter; je veux le faire par la qualité des oeuvres données. Et puis comme étranger je dois éviter de faire croire que je voudrais exercer une pression quelconque sur le goût français. C'est pourquoi je préfere LETTRES quoique ce titre ne me satisfasse pas pleinement. C'est un peu terne mais n'a d'autre signification que l'alphabet et ce qu'on en fait.

De wat bescheiden toon, die zeker niet bij hem paste, verliest Church al snel: vanaf het moment dat het eerste nummer is verschenen, staan zijn brieven vol oordelen over teksten en auteurs en houdt hij menige suggestie van Paulhan tegen. Zijn brieven bevatten echter niet alleen informatie over het tot stand komen van de nummers van Mesures, zij geven ook inzicht in het dagelijks leven van een rijke, cosmopolitische, kunstzinnige intellectueel in het interbellum.

Church leeft van de opbrengst van het familiekapitaal en gebruikt zijn geld, afgaand op de gegevens in de brieven aan Paulhan, in de eerste plaats om de literatuur te begunstigen. Buiten de financiering van Mesures, die hem naarmate de economische situatie verslechtert steeds zwaarder valt, geeft hij aanzienlijke sommen geld aan auteurs die steun nodig hebben. Paulhan kan altijd een beroep op hem doen voor een auteur in nood, zo laat hij meer dan eens weten. Church noemt onder anderen René Daumal, Alix Guillain en Bernard Groethuysen als personen die zijn hulp misschien nodig hebben. In 1939 en na het uitbreken van de oorlog stuurt hij zolang het kan vanuit de Verenigde Staten geld naar Europa en verzoekt Paulhan het geld naar zijn goeddunken te verdelen. Een brief van eind 1939 bevat bijvoorbeeld de volgende passage:

Avez-vous des nouvelles de Schloezer? Tachez de savoir comme ils vont, s'ils ont besoin d'une aide matérielle. Et s'il y a d'autres, amis ou inconnus, qui ont besoin de notre appui, n'hésitez pas à nous écrire. Pour une oeuvre aussi si vous en connaissez. 
Church en zijn echtgenote Barbara, die van Duitse afkomst was, bewonen in de tijd van Mesures een riant huis in Ville-d'Avray bij Parijs. Daar vinden de exclusieve 'déjeuners Mesures' plaats en worden concerten gegeven in het speciaal ontworpen paviljoen achterin het park dat het huis omgeeft. Ook het vuurwerk, waarnaar hier en daar wordt verwezen, wordt daar op mooie zomeravonden afgestoken - Church' hartstocht voor vuurwerk is ongetwijfeld verbonden met zijn scheikundige belangstelling. In de zomermaanden komen de brieven uit hotels in Zwitserland (Vulpera, St.Moritz, Ragaz) en tussendoor worden reisjes naar Duitsland, Spanje en Italië ondernomen. Ook in de Verenigde Staten en Canada waar de Churches vanaf midden 1939 verblijven wordt veel gereisd: het Plaza Hotel in New York is de uitvalsbasis, maar de brieven komen ook uit Princeton, Hartford, Seattle en Quebec. Dit fysieke cosmopolitisme gaat vergezeld van een cosmopolitisme van de geest. Church is even goed op de hoogte van de literaire traditie als van de nieuwste trends in de literatuur en wijdt net zo makkelijk een paar zinnen aan een tekst van Shakespeare, Goethe of Nietzsche als aan een tekst van Lewis Carroll, Rilke of Eluard. Hij leest detectives, van Simenon onder anderen, en beklemtoont het feit dat hij van lectuur houdt in tegenstelling tot Paulhan die hij enigszins plagerig 'Schöngeisterei' verwijt.

Inmiddels is voldoende duidelijk dat Church zowel actief (als schrijver, vertaler, redacteur en mecenas van Mesures), als passief (als onverzadigbaar lezer) aan het literaire leven van zijn tijd deelneemt. Uit zijn brieven komt hij bovendien naar voren als een volstrekt onafhankelijk criticus die alles wat hij leest maar volgens één criterium beoordeelt: dat van de kwaliteit. Ook muziek, schilderkunst en architectuur komen wel aan de orde, maar literatuur staat duidelijk nummer één.

De ontwikkelingen in Duitsland (waar hij enige tijd gewoond heeft) en de reacties daarop elders in Europa volgt Church op de voet. Hij leest Franse, Duitse en Engelstalige kranten, ongeveer tien per dag, hij luistert naar de radio en geeft regelmatig zijn visie op de situatie. Met enige ironische distantie ontleedt hij het optreden van Hitler in het midden van de jaren dertig. Later, vanaf eind '39, schrijft hij vanuit de Verenigde Staten over gevoelens van psychische verlamming, desillusie en depressie die hij, zonder succes, probeert te verjagen door te lezen en muziek te maken. Zelf wijt Church deze staat in de eerste plaats aan de oorlog, maar het gemis van de Parijse 
contacten en het gebrek aan artistieke en intellectuele stimuli zijn daar zeker ook debet aan, zoals hij en vooral Barbara Church lijken te beseffen. Uit de brieven komt een zekere belangstelling voor politieke kwesties, voor filosofische problemen en voor wetenschappelijke ontwikkelingen naar voren, maar Church lijkt toch in de eerste plaats een onconventioneel literatuurliefhebber geweest te zijn. Church was slordig (hij is voortdurend van alles kwijt, de handgeschreven brieven zijn nauwelijks te ontcijferen en de enorme hoeveelheid fouten in het getypte materiaal laat hij maar staan), zijn oordelen over mensen en situaties zijn scherp en geestig, en zelfs het milde antisemitisme dat uit zijn brieven spreekt (vermeldingen als 'un juif, 'une jolie juive', 'une soirée judéo-communiste', 'une pseudo-profondeur très juive' komen wel erg vaak voor) past bij zijn status en zijn tijd. Het beeld van Church dat uit deze brieven naar voren komt, wijkt daarmee niet sterk af van het beeld dat bestaat van zovele rijke kunstliefhebbers uit de eerste helft van de twintigste eeuw. Interessant zijn deze documenten vooral omdat zij het mogelijk maken, hoe lapidair ook, de geschiedenis van Mesures te volgen en er zo duidelijk het einde van een tijdperk in is waar te nemen: Church' desillusie en machteloosheid van 1939 tot aan zijn overlijden in 1947 lijken voort te komen uit het besef dat de wereld nooit meer dezelfde zal worden.

\section{COMMERCE - MESURES}

Church vervulde voor Mesures de rol die Marguerite Caetani - ook zij kwam uit Amerika en 'vluchtte' aan het begin van de eeuw naar Europa voor Commerce heeft vervuld. ${ }^{10}$ Het is zelfs zo dat alle documenten waarin de oprichting van Mesures aan de orde komt, laten zien dat Church met zijn tijdschrift de vrijgekomen plaats - het laatste nummer van Commerce was in de lente van 1932 verschenen - wilde opvullen. Aangespoord door Church lijkt Paulhan de herinnering aan het goedbetalende en elitaire Commerce zeer bewust gebruikt te hebben om Mesures van medewerkers te voorzien.

Niet alleen de beoogde status is gelijk, ook qua typografie en inhoud zal Mesures op Commerce gaan lijken. Vier ingrediënten zijn nodig om het recept te laten slagen: nieuw talent, buitenlanders, onbekende of vergeten teksten en niet-Westerse literatuur, of in de woorden van Church: 'welke Hindoe, welke Chinees nemen we op?' In zijn brieven aan Paulhan geeft Church, die, vooral in het begin, eigenlijk iedere tekst die voor Mesures is bestemd uitge- 
breid wil bediscussiëren, commentaar bij elk van deze vier ingrediënten. Overigens mikt hij niet op imitatie maar op emulatie, want voordat er één nummer verschenen is, schrijft hij al aan Paulhan ervan overtuigd te zijn Commerce te kunnen overtreffen.

Wat Paulhans gedachten waren bij dit alles laat zich niet vaststellen. In zijn correspondentie met de ouderen (Ungaretti, Gide, Larbaud) gebruikt hij de herinnering aan Commerce om Mesures van de grond te krijgen. In zijn pogingen jongeren voor het blad te interesseren doet hij dat ook, maar lijkt hij er tevens achter te willen komen of Mesures naar hun mening wel op de juiste weg is als het zich zo modelleert naar het geïdealiseerde voorbeeld. Ongetwijfeld omdat hij zich realiseert dat Commerce weliswaar in de jaren twintig bloeide, maar dat de jaren dertig andere eisen stellen. Zo schrijft hij begin 1935 aan Francis Ponge:

imagine que tu as à diriger Mesures: dis moi ce que tu penses du no 1, et ce qu'il faut faire, dans les suivants,

1. pour être très bien

2. pour n'être ni la NRF ni Commerce?

Ponge antwoordt per ommegaande en neemt bepaald geen blad voor de mond:

Si Mesures continue à offrir au moins autant de textes étrangers que de français, et une proportion constante d'auteurs morts et de vivants, ce ne sera ni la NRF ni Commerce. Le choix des collaborateurs y sera pour beaucoup aussi (bien sûr). Il faudrait donner des inédits de Joyce, Ungaretti, Gorki, Kassner. A part les cinq ou six noms indispensables (Gide, Fargue, Larbaud, Claudel, Valéry) je vois: Jouhandeau, Michaux, Paulhan, Groethuysen, Ponge, Eluard (si possible), Dabit, Daumal, (...) Enfin je crois que Mesures serait l'occasion de laisser tomber les valeurs secondaires de la NRF: Supervielle, Drieu, Arland, Suarès. ${ }^{11}$

Weliswaar haast Ponge zich te zeggen dat dit soort opsommingen ridicuul is en Paulhan niet echt zal helpen, een regel verder gaat hij alweer precies 
zo door en geeft hij Paulhan de suggesties waarnaar deze, ervaren tijdschriftredacteur, nu juist heeft gevraagd.

Enige tijd later, in 1937, overlegt Paulhan over de koers van Mesures met Roger Caillois, die sinds eind 1935 regelmatig aan de NRF bijdraagt. Interessant is de volgende passage uit een brief van Caillois aan Paulhan van 29 juli 1937:

Venons à Mesures. Certes cette revue n'est pas ce qu'elle veut et pourrait être. Cela tient d'ailleurs moins, à mon avis, à ses collaborateurs qu'à l'idée qu'ils se font d'elle. Dans cette idée, le souvenir de Commerce est certainement despotique. Les préoccupations ne sont plus les mêmes qu'au temps de cette dernière publication. Or, pour m'en tenir aux textes moyen-âgeux et autres ressuscités, ceux de Mesures continuent exactement ceux de Commerce (genre alchimistes précurseurs, etc.). Peut-être faudrait-il inaugurer une nouvelle direction. ${ }^{12}$

Met de suggesties die Caillois vervolgens doet om het blad te verbeteren, met name met diens idee een rubriek in het leven te roepen waarin hij onder de noemer 'phénoménologie générale de l'imagination' zelf bijdragen levert, is Paulhan zo ingenomen dat hij belooft Church voor te stellen om Caillois in de redactie op te nemen. Caillois is enthousiast en begint op verzoek van Paulhan vast het een en ander te prepareren. Church is echter minder te spreken over de ideeën van Paulhan en Caillois. Op 22 juli 1937 maakt hij Paulhan, die hem kennelijk al over Caillois heeft geschreven, duidelijk dat hij deze geen vaste rubriek wil geven.

Je verrais volontiers de temps à autre un article de Caillois dans Mesures. Mais lui confier une chronique pour 4 numéros me paraît... Il est encore trop jeune. En outre il voudrait donner une ligne à Mesures. Pourquoi imposer aux malheureux lecteurs de Mesures, déjà si accablés une ligne?

Hij lijkt bijna gekwetst als hij op 17 augustus 1937 vanuit St.Moritz schrijft dat het programma van Mesures toch juist is dat het tijdschrift geen vast programma heeft, en dat onder andere laat blijken uit de diversiteit van de tek- 
sten. We geven een van onze kostbaarste principes op als we iemand die niet bij het tijdschrift hoort, vragen onze programmatische lijn uit te zetten, zo schrijft hij.

C'est nous qui avons créé Mesures, nous qui la dirigeons; pourquoi donner à un homme plus jeune que nous une part si grande dans la direction de la revue?

Caillois heeft overigens een goede indruk gemaakt en Church vindt het best als hij voor het oktobernummer nog een kroniek schrijft, maar verder wil hij geen verbintenissen aangaan. In de jaren die volgen wordt Mesures regelmatig besproken tussen Paulhan en Caillois. Deze draagt in totaal drie teksten bij aan het blad, maar lid van de redactie wordt hij niet. Zoals Marguerite Caetani bij Commerce wel eens van haar vetorecht gebruik maakte en bij moeilijke beslissingen in ieder geval altijd het laatste woord had, zo lijkt ook Church zijn rol bij Mesures gespeeld te hebben. Paulhan zal meer dan eens gezucht hebben als hij moest laveren tussen de principes en wensen van de mecenassen uit Amerika, de ideeën van de jongeren en zijn eigen opvattingen over de koers van een tijdschrift. ${ }^{13}$

Mesures: HET REDACTIECOMITÉ, DE VERSPREIDING

De naam van het nieuwe tijdschrift is na veel deliberaties uiteindelijk vastgesteld door Paulhan, Church en diens echtgenote, die van het begin tot het eind niet minder nauw bij de onderneming was betrokken dan Church zelf. De keuze van de redactieleden buiten Paulhan en Church is niet moeilijk te verklaren. Ungarettti en Groethuysen waren beiden, onofficieel, bij Commerce betrokken; de eerste om suggesties te doen met betrekking tot de Italiaanse letterkunde, de tweede om het blad te voorzien van oude, onbekende teksten, een genre dat hij bij zijn naspeuringen in bibliotheken en archieven regelmatig tegenkwam. Op verzoek van Church en Paulhan zetten zij deze activiteiten, nu officieel, voort in de redactie van Mesures.

Michaux was een van de favoriete 'jeunes' van Marguerite Caetani en hij zal ook zeker door Church en Paulhan bij Mesures gevraagd zijn om op deze wijze jong talent een plaats in het blad te geven. ${ }^{14} \mathrm{Hij}$ laat zich echter met moeite overhalen om deel uit te maken van het comité en gebruikt als ar- 
gumenten voor een aanvankelijke weigering zijn vele reizen en de overtuiging dat redactielidmaatschappen zijn roeping niet zijn. Uiteindelijk zwicht hij toch en ofschoon uit het beschikbare materiaal niet duidelijk wordt of er teksten door zijn bemiddeling in Mesures terecht zijn gekomen, is hij in ieder geval één keer aanwezig geweest bij een redactievergadering. ${ }^{15}$

De Paulhans, de Groethuysens en een aantal Mesures-auteurs waren regelmatig te gast in Ville-d'Avray, maar over de frequentie van de vergaderingen is niets te vinden. ${ }^{16}$ Wat de financiering en verspreiding van het tijdschrift betreft zijn er evenmin voldoende gegevens om een totaalbeeld te construeren, maar dat het blad geen commercieel succes is, laat zich raden. Voordat het eerste nummer uitkomt, waarschuwt Paulhan Larbaud dat Mesures armer is dan Commerce en zijn auteurs per bladzij dus minder kan betalen. In de briefwisseling Church - Paulhan wordt hier en daar over honoraria voor de redactieleden gesproken. Aan Paulhan biedt Church bij het begin van de onderneming 4000 francs voor ieder nummer dat verschijnt en er wordt een enkele maal gemarchandeerd over de kosten van een vertaling. De oplagecijfers worden aan het eind van ieder nummer vermeld, en daardoor is te zien dat de oplage met ingang van de derde jaargang (1937) zakte van 1800 naar 1200 exemplaren. Hetgeen duidelijk maakt dat noch de circulatie van het tijdschrift groter werd, noch het aantal abonnees (300 is het enige cijfer dat bekend is) groeide. De koper betaalde voor een los nummer 15 francs, een jaarabonnement kwam op 50 francs.

Vanaf 1937 vraagt Church zich zo af en toe af of de onderneming nog wel kan worden voortgezet. In de zomer van dat jaar wordt er echt op maatregelen gezonnen. Church heeft met Adrienne Monnier gesproken en zij heeft hem duidelijk gemaakt hoe Mesures er voor staat. Hij geeft de informatie aan Paulhan door in een brief gedateerd 21 juli:

Elle m'a dit qu'on ne la lisait plus parce qu'on avait les mêmes auteurs dans la NRF et en plus le bulletin et l'air du mois. En outre elle m'a appris que Gallimard n'en vendait plus, qu'Emile Paul avait demandé la suppression du dépôt. J'ai donc trouvé inutile de lui demander d'augmenter le nombre des dépositaires.

Elle trouve assez bonne mon idée de réduire le prix. Car, si j’ai bien com- 
pris, nos lecteurs étant front populaire se gênent d'être vus avec un tel déploiement de luxe dans les mains.

Church wil de kwestie in september met Paulhan bespreken, ze moeten misschien maar helemaal stoppen, verzucht hij. Maar eigenlijk voelt hij daar niets voor en ook Barbara laat weten dat zij denkt dat er wel een middel zal worden gevonden om het tijdschrift te laten voortbestaan.

Paulhan wacht niet tot na de zomer, maar doet Church een paar wijzigingsvoorstellen. Deze reageert op 23 augustus:

A propos de réclame, vous dites qu'il faut organiser la propagande. Avezvous des idées neuves là-dessus? Dites-les-moi. Oui nous pourrions garder le même format, et périodicité, le papier aussi puisque vous tenez à une revue de luxe. Mais il serait temps, à mon avis, d'abandonner les gros caractères, même pour les vers. Ce sera une économie importante et nous permettra de donner plus de texte, si nous restreignons le nombre des pages.

Een andere manier om de kosten te drukken, is het weren van dure auteurs. Dan maar geen Claudel of Valéry of Suarès, vindt Church. Of ze moeten maar met een wat minder hoog honorarium genoegen nemen.

De briefwisseling laat zien dat Mesures de zorgen kende van iedere tijdschriftredactie in een periode dat de economische situatie overal steeds nijpender werd. Voor Mesures bleven het zorgen, ondanks de aanpassingen in de betaling en de oplage, totdat het tijdschrift, na het tweede nummer in 1940, helemaal niet meer verschijnen kon.

Van Ungaretti's redacteurschap zijn de meeste sporen bewaard. In de correspondentie Paulhan - Ungaretti worden het tijdschrift en de daarmee verbonden kwesties vanaf de herfst van 1934 tot in 1948 met grote regelmaat genoemd. 'Magnifique', 'superbe', 'admirable', zo luiden Ungaretti's oordelen over de eerste nummers. Hij bericht Paulhan dat de Romeinse boekhandels ('La Modernissima' en 'Libreria internazionale Trèves' worden met name genoemd) zich erover beklagen dat ze slechts één exemplaar in handen hebben gekregen en laat weten dat alle kranten (Tribuna en Gazzetta del Popolo) het blad vol lof hebben besproken. ${ }^{17}$ Afgaand op de briefwisseling met Paulhan kende Ungaretti's redacteurschap drie aspecten: het becommentariëren 
van teksten en auteurs (Italianen en anderen), het suggereren van bijdragen van oude en nieuwe Italiaanse schrijvers en het maken van propaganda voor het tijdschrift, eerst in Italië, later in Brazilië, waarheen hij begin 1937 met vrouw en kinderen verhuisde. Het tastbare resultaat van Ungaretti's bemoeienissen met Mesures is veel minder groot dan de vele ideeën, suggesties en oordelen en vooral de eindeloze namenrij in de correspondentie met Paulhan, zouden doen vermoeden. Uiteindelijk staat alleen van de teksten van Bruno Barilli, Marcello Gallian en van hem zelf vast dat ze door zijn bemiddeling in Mesures zijn opgenomen.

Zoals eerder opgemerkt, is een groot deel van de 'anciens textes' via Groethuysen in Mesures terecht gekomen. Door zijn banden met de NRF eh door hun lange vriendschap stond hij dicht bij Paulhan. Ook Church noemt zijn naam vaak en vol waardering. Heel opmerkelijk is het dat Church op 5 februari 1935, als er net één nummer van Mesures is uitgekomen, aan Paulhan schrijft dat er twee manieren zijn om een tijdschrift op te richten, ofwel via een reeds bestaande groep auteurs, ofwel door een groep in het leven te roepen als het tijdschrift is opgericht. Desalniettemin stelt hij op 4 oktober van hetzelfde jaar voor het redactiecomité maar af te schaffen. Hij geeft daarvoor twee redenen: ten eerste zal het de kosten drukken, ten tweede speelt het comité toch maar een ondergeschikte rol, waardoor het tijdschrift net zo goed zonder kan, zeker als Barbara en hijzelf wat meer werk verzetten. In de loop van de eerste drie jaar komt Church hier nog een paar keer op terug, maar Paulhan heeft gelukkig kunnen voorkomen dat dit idee werd uitgevoerd.

\section{Mesures: DE POËTICALE UITGANGSPUNTEN}

Geen ander programma kan er zijn dan de diversiteit van de teksten, zo vindt Church. Mar met behulp van andere uitspraken is er toch wel enige precisering aan te brengen in dit zeer liberale standpunt. Kwaliteit is het enige criterium dat Church zegt aan te leggen bij het beoordelen van teksten en hij wil dat Mesures dat overneemt. In de brieven aan Paulhan is goed te volgen hoe Church dit vage criterium, dat uitgaat van een consensus over 'hoge' literatuur waarover in zijn kringen toen niemand problemen makte, langzaamaan expliciteert en uitbreidt. Kwaliteit betekent in de eerste plaats 'tout ce qui frappe par une note neuve, personnelle, et qui soit bien écrit. (Surtout bien et intelligemment écrit).' Een tekst dient bovendien afgerond 
te zijn, niet een onaffe poging. In twee achtereenvolgende brieven probeert Church zijn opvatting te verduidelijken:

Nous voulons publier des jeunes, nous en cherchons; mais il faut que ce qu'ils offrent soit définitif, pas un essai.

Il me semble qu'une oeuvre imparfaite peut être définitive. Par définitif, j'entends une oeuvre qui offre de l'unité, de l'harmonie, qui soit bien écrit ou mieux, intelligemment écrit, une pensée soutenue, substantielle, une oeuvre enfin qui apporte en même temps et du neuf, et l'empreinte d'une personnalité. Mais cette oeuvre peut fort bien être marquée par l'imperfection. Mais surtout elle ne doit pas être un tâtonnement.

Dit zijn citaten uit 1934, uit de tijd dat het eerste nummer in voorbereiding was. Later worden Church' uitlatingen concreter, zeker vanaf het moment dat er reacties komen van medewerkers, zoals van Caillois en van Adrienne Monnier, die hierboven zijn aangehaald.

Church becommentarieert de teksten die Paulhan hem toezendt van Claudel, Fargue, Jouhandeau, Daumal, Henry Miller, Alfred Döblin, E.M. Forster, en vele anderen. Eén punt komt steeds weer naar voren: Mesures moet meer jongeren publiceren, dan zal het tijdschrift ook meer waardering van een jonger publiek krijgen. Uitspraken als: 'MESURES demeure trop inféodées à la NRF', 'Je vous l'ai dit au début: toujours le même népotisme' en '...toujours le même cycle. C'est cela que je crains le plus', zijn legio in de brieven aan te wijzen. Om de nieuwe wegen te vinden die Mesures zoekt, is een nadere precisering van de programmatische uitgangspunten noodzakelijk volgens Church. In 1937 schrijft hij zelfs:

Mais alors c'est de la polémique que vous voulez faire. Dans ce cas, il faudrait, pour rester dans la tradition de Mesures demander une article, soit à Romains, soit à Maurois sur nous et nos tendances. (...) Si nous faisons de la polémique, je préférais qu'elle fût politique.

Waartoe Church' combinatie van diversiteit, kwaliteit en jeugdig élan heeft geleid, toont ons de inhoud van het tijdschrift zelf. Dat Mesures voor Church echter nooit de ideale combinatie van deze drie elementen heeft bevat, is een 
gedachte die bij het lezen van zijn brieven steeds sterker naar voren komt. Waarschijnlijk was hij, in tegenstelling tot Paulhan, toch niet voldoende ingevoerd in de dagelijkse praktijk van een tijdschriftredacteur om te beseffen van hoeveel factoren het samenstellen van een nummer iedere keer afhangt. Church regeerde op afstand en kon zich daardoor de luxe veroorloven te blijven geloven in het ideaal.

Een culminatie van wat hij zocht, lijkt Church gevonden te hebben in het werk van de Oostenrijker Robert Musil van wie in 1935 en 1937 teksten in Mesures hebben gestaan. In 1934 schrijft Church aan Paulhan:

Je lis Musil, Mann ohne Eigenschaften, c'est formidable, colossal, mais terriblement difficile à lire. Il faudrait le faire connaître au public français. Peut-être un grand écrivain, un Proust ou un Stendhal, comparaison assez sotte.

De volgende keer dat Church Musil noemt, is in augustus 1938. Hij brengt Paulhan op de hoogte van het feit dat hij met Musil correspondeert en dat deze met zijn vrouw bij hem en Barbara zullen langskomen in Vulpera, tenminste als Mesures een voorschot wil verstrekken voor aforismen die hij (Musil) dan later kan leveren. Church wil hem graag ontvangen en helpen. Hij spreekt het vermoeden uit dat Musil niet meer terug zal willen gaan naar zijn eigen land en vraagt Paulhan of er in Parijs iets voor hem gedaan kan worden. Church denkt aan 'un emploi de leçons, n'importe quoi.' In een volgende brief - Musil en zijn vrouw zijn dan inmiddels op bezoek geweest - beschrijft Church hoe ongerust en rusteloos zij beiden zijn in hun nieuwe, onwennige emigrantenstatus. Weer vraagt hij Paulhan of deze een oplossing voor ze weet; hij zal zelf natuurlijk ook het nodige blijven doen, maar hij wenst Musil niet als een last op zijn schouders te nemen.

In 1945 probeert Church het werk van Musil in de Verenigde Staten te introduceren. Hij schrijft op 24 april 1945 aan Wallace Stevens met wie hij dan al enige jaren bevriend is:

Dear Mr. Stevens,

(...)

Did you ever hear of an Austrian novelist Robert Musil? He was a great 
friend of ours, he died a year ago. He only wrote one important book and he didn't finish it: the Mann ohne Eigenschaften. I want to get a few pages translated for Tate with a critical sketch. I counted on Erich Kahler to do it. He was a friend of Musil. But he tells me he is too busy. Do you happen to know a german scholar here or elsewhere who might be capable of doing it. It really is a great book.

Stevens doet een suggestie, maar Church wil deze in portefeuille houden want op dat moment maakt een jonge Weense man, wiens naam niet wordt genoemd, op zijn verzoek een proefvertaling. De laatste Musil-vermelding is van oktober 1946. Church is dan even terug in Frankrijk en schrijft aan Paulhan vanuit het huis in Ville-d'Avray, dat in de oorlog door bezetters is bewoond, dat Barbara Church de passages van Musil die in Mesures hebben gestaan voor Allen Tate, op dat moment redacteur van. The Sewanee Review, heeft vertaald.

Aanwijzingen waarmee de vraag beantwoord kan worden waarom nu juist het werk van Musil Church zo aansprak, heeft deze zelf niet gegeven. Woorden als 'formidable', 'colossal' en 'great' komen niet vaak in zijn brieven voor en als hij al dergelijke hyperbolen gebruikte dan eerder over het werk van Shakespeare of Goethe dan over dat van een tijdgenoot. Een verklaring moet, lijkt mij, gezocht worden in de ironische distantie waarmee Musil de wereld in Der Mann ohne Eigenschaften schetst. De wijze waarop alle denkbare ethische, filosofische en politieke posities die in de cyclus voorkomen worden onderzocht en vervolgens verworpen, moet Church zeer hebben aangesproken. Zo zeer zelfs dat hij de voortgang van het werk gunstig hoopte te kunnen beïnvloeden door Musil financieel en moreel te steunen. In ieder geval leverden Musils werk- en levenshouding, waarin Church veel herkend zal hebben, literatuur naar zijn hart. ${ }^{18}$

\section{Mesures: DE INHOUD}

Op 15 januari, 15 april, 15 juli en 15 oktober kwam Mesures uit, zonder onderbreking vanaf het eerste nummer in 1935 tot in 1940, toen slechts twee nummers werden uitgebracht. In totaal verschenen 22 nummers van gemiddeld 200 pagina's ieder. De redactie geeft in het eerste nummer in een paar regels haar programma. Mesures neemt zich voor 'de publier hors de toute 
mode, école, doctrine les oeuvres des meilleurs écrivains français et étrangers et des textes philosophiques, mystiques ou anciens.'

Claudel, Fargue, Jouhandeau en Ponge waren de Franse tijdgenoten in het eerste nummer, Gide figureert in de inhoudsopgave als vertaler van een verhaal van Poesjkin. Het aantal negentiende-eeuwse auteurs komt met Gerard Manley Hopkins en Balzac op drie. Musil, Pirandello en de Engelse Dorothy Richardson zijn de buitenlandse tijdgenoten. Op het eerste gezicht een buitengewoon geslaagde imitatie van een nummer van Commerce, maar een nauwkeuriger vergelijking van dit en andere nummers van Mesures met nummers van de voorganger brengt karakteristieke verschillen aan het licht.

In het eerste nummer van Mesures worden Musil, Hopkins en Richardson met een korte biografie bij de lezer geïntroduceerd, de tot dan toe niet eerder gepubliceerde 'préface' van Balzac wordt met een tekst van vier bladzijden ingeleid en de gedichten van Hopkins staan tweetalig afgedrukt. Inleidingen, biografieën en presentaties van de brontekst naast de vertaling komen in Mesures veel vaker voor, in Commerce was deze dienst aan de lezers vrijwel taboe. Helemaal te doorgronden is de strategie van de Mesures-redactie in deze overigens niet. Waarom Garcia Lorca in nummer 2 niet geïntroduceerd en Macleish wel? Waarom de nauwelijks bekende Zwitserse filosoof Henri Frédéric Amiel in nummer 3 wel ingeleid, de op dat moment niet veel bekendere Martin Heidegger niet, maar Martin Buber weer wel (respectievelijk in de nos. 3 en 4 van 1937)?

Een volgend kenmerk van Mesures dat in nummer 1 is aan te wijzen en vervolgens doorzet, is de belangstelling voor de late achttiende en de negentiende eeuw. Met teksten van Amiel, Balzac, Baudelaire, Emily Dickinson, Dostojevskij, Benjamin Franklin, Gezelle, Hegel, Hölderlin, Hopkins, Kierkegaard, Kleist, Poe, Poesjkin, Swift, Tolstoj en Whitman is deze periode tot in alle decennia en vele nationale letterkundes zeer goed vertegenwoordigd.

Het accent ligt met betrekking tot de 'anciens textes' dan ook eerder in de negentiende eeuw dan in een vroegere periode, hetgeen betekent dat Mesures de modernistische voorkeur voor teksten uit de Renaissance, die Commerce zo duidelijk uitdroeg, niet deelt. ${ }^{19}$ Wat weer wel van Commerce is overgenomen, is de aandacht voor niet-Westerse letterkundes. In Mesures zijn onder andere vertalingen uit het Chinees, Tibetaans, Syrisch-Chaldeeuws en Arabisch te vinden. Het principe om waar mogelijk dichters door dichters 
te laten vertalen levert interessante duo's op: Garcia Lorca en Brecht worden vertaald door Jean Prévost, Stefan George door Catherine Pozzi, ${ }^{20}$ Constantin Kavafis door Marguerite Yourcenar en Musil, ten slotte, door Barbara Church.

In 1936 schrijft de redactie drie prijsvragen uit: wie wil kan achtereenvolgens meedingen naar een 'prix de poésie', een 'prix du récit bref en een 'prix de la traduction'. Met iedere prijs is een bedrag van 3000 francs te winnen en er geldt slechts een voorwaarde voor deelname: 'il n'est imposé aux concurrents d'autre condition que d'être peu ou point connus'. De inzendingen worden door de redactie beoordeeld en de teksten van de winnaars en van een aantal anderen worden gepubliceerd in de nummers 2, 3 en 4 van de tweede jaargang. Mesures is op zoek naar jong talent en te oordelen naar het aantal inzendingen (7oo gedichten voor de poëzieprijs, 162 vertalingen voor de vertaalprijs) is de poging in contact te komen met (jonge) lezers bij het publiek in ieder geval niet onopgemerkt gebleven.

Deze prijsvragen zijn een antwoord op de klachten van Church in zijn brieven aan Paulhan. Waarschijnlijk is de Amerika-special, die als het derde nummer van 1939 verschijnt, ook bedoeld als een signaal aan de lezers dat Mesures een nieuwe koers zoekt. Sylvia Beach heeft de redactie geholpen bij het totstandkomen van dit nummer, dat bijna 400 bladzijden telt. Het bevat essays, proza en poëzie uit de achttiende en de negentiende eeuw, maar vooral heel veel nieuwe auteurs uit de twintigste. Hart Crane, John Dos Passos, Henry Miller, Marianne Moore, Wallace Stevens, Allen Tate en William Carlos Williams en anderen zijn hier vaak voor het eerst in het Frans vertaald, in de meeste gevallen door Raymond Queneau en Pierre Leyris. Of de redactie in haar opzet is geslaagd met deze anthologie de belangstelling voor Amerikaanse literatuur te stimuleren, staat niet vast. Zeker is wel dat de belangstelling voor Mesures in de Verenigde Staten door dit project is toegenomen.

Mesures: 1939, 1940

Medio 1939 reizen de Churches naar New York. Het verblijf in de Verenigde Staten dient om familie te bezoeken, contacten te leggen of te vernieuwen en om de oorlogsdreiging in Europa enige tijd te ontlopen. Vanaf het begin van de correspondentie met Paulhan becommentarieert Church 
regelmatig de politieke situatie. Hij leest zoals vermeld veel kranten en baseert zijn sombere, voorspellingen op eigen en andermans analyses. Hij lijkt zich bijzonder weinig illusies te maken over de gevolgen die Hitlers machtsovername zal hebben.

Het is aanvankelijk niet de bedoeling om in de Verenigde Staten te blijven (Parijs wordt vrijwel direct vreselijk gemist) en in een brief van september 1939 uit Church de wens zich te laten naturaliseren tot Fransman. Een andere manier om zo snel mogelijk terug te kunnen keren is met een visum, maar Church heeft vernomen dat visa heel moeilijk te krijgen zijn. Kan Paulhan iets voor hem doen? Hij zou zeer geholpen zijn met een brief van het Ministerie van Buitenlandse Zaken aan het Amerikaanse State Department waarin staat 'que la France serait très heureuse de voir rentrer le directeur de Mesures', of woorden van gelijke strekking.

De mogelijkheden om naar Europa terug te keren worden met iedere brief kleiner. De post doet er steeds langer over en het wordt steeds moeilijker om geld te sturen. Als Barbara Church op 18 mei 1940 laat weten dat zij eindelijk hun paspoorten hebben, is de volgende boodschap in dezelfde brief dat zij desondanks in Amerika zullen blijven.

De uitwisseling over Mesures verloopt in 1939 regulier. Church laat Paulhan weten wat hij leest (Enid Starkie, Rimbaud, Baudelaire), wat hij doet (piano spelen, theater en bioscoop bezoeken en veel naar de radio luisteren) en wie hij ziet (Auberjonois, Allen Tate en 'les deux directrices de Twice a Year, Dorothy Thompson en Mme Lescazes).21 Paulhan stuurt manuscripten ter beoordeling en houdt Church zo goed mogelijk op de hoogte van het wel en wee van de vrienden in Frankrijk.

Op 12 februari 1940 vraagt Church zich af of Paulhan er in zal slagen nog een nummer uit te brengen, op 10 april is het eerste nummer van 1940 eindelijk in New York. Church hoopt tot het eind van het jaar dat Mesures kan blijven verschijnen en overlegt over teksten voor volgende nummers, 'Oui, envoyez nous des ms pour que nous ayons le sentiment de nous occuper un peu de la revue.' Maar het tweede nummer van 1940, van 15 april, is het laatste reguliere nummer van het tijdschrift.

In en vooral na de oorlog zijn er direct plannen voor een voortzetting van Mesures. Deze hebben nog niet tot een resultaat geleid als Church, die, zoals reeds vermeld, in 1946 korte tijd naar Parijs terugkeert, in april 1947 
in New York overlijdt aan de gevolgen van de hartkwaal waarvan hij al jaren last heeft. ${ }^{22}$

MOTIEVEN

Nadere bestudering van een van de Amerikaanse contacten van Church geeft meer inzicht in de motieven van zijn mecenaat, dat zich zeker niet beperkte tot het financieren en bevorderen van de publicatie van interessante teksten alleen.

Wallace Stevens, die vanaf het eerste nummer abonnee was van Mesures, wordt aan het begin van 1939 door Church benaderd met de vraag of er in de Amerika-special teksten van hem mogen worden opgenomen. Stevens stemt toe en stuurt vervolgens een uitgebreide reactie op de vertalingen. ${ }^{23}$ In zijn brief van 1 juni 1939 schrijft hij dat hij de zaak wel in orde zal brengen bij zijn uitgever Knopf. En passant doet hij nog een suggestie voor een gedicht dat hij in een buitenlandse bloemlezing van zijn eigen teksten zou opnemen als hij het voor het zeggen had. Stevens geeft de korte biografie die Church heeft gevraagd, omdat in het Amerika-nummer van alle auteurs een levensbeschrijving wordt opgenomen en vervolgt:

What counts, I suppose, is one's relation to contemporary ideas. Much of that, however, would be irrelevant as part of an introduction to a group of poems obviously having nothing to do with the ideas of the day in which they were written, nor of today. I am, in the long run interested in pure poetry. No doubt from the Marxian point of view this sort of thing is incredible, but pure poetry is rather older and tougher than Marx and will remain so. My own way out toward the future involves a confidence in the spiritual role of the poet, who will somehow have to assist the painter, etc. (any artist, to tell the truth) in restoring to the imagination what it is losing at such a catastrophic pace, and in supporting what it has gained.

Deze passage is Church zeker bevallen. Er ontwikkelt zich een, wat afstandelijke, vriendschap tussen hem en Stevens, er ontstaat een frequente briefwisseling en er vindt een aantal ontmoetingen plaats. Uit alle gegevens blijkt dat hun standpunten veel overeenkomsten vertonen: zij delen een ethische 
houding en een humanistische levensopvatting, maar van de wat hinderlijke aspecten die daarmee vaak verbonden zijn lijken geen van beiden last te hebben. Kunst en de rol en de status van poëzie in de samenleving zijn de belangrijkste onderwerpen in hun uitwisseling.

Als eenmaal duidelijk is dat Mesures niet in Frankrijk kan verschijnen zolang Europa in oorlog is, wordt het plan opgevat het tijdschrift voort te zetten in de Verenigde Staten. Eind mei 1940 raadt Stevens Church aan contacten te leggen op Princeton University, want 'there is a chance that the literary group at Princeton has considered publishing something of the kind that you have in mind'. ${ }^{24}$ Als Church Edmund Wilson, 'the Axel's Castle Man', zo ver zou kunnen krijgen dat hij voor de teksten uit Amerika gaat zorgen, zoals Church dat kan voor teksten uit Europa, dan zou de 'nucleus' die het blad nodig, heeft al gevormd zijn.

In de maanden die volgen wordt er een aantal namen van personen en tijdschriften genoemd waarmee Mesures zich zou kunnen verbinden (Lawrence Thompson, John Crowe Ransom, Southern Review, Kenyon Review, Partisan Review). Met een dergelijke stap zou Church echter direct in allerlei literaire politiek verwikkeld raken, zo waarschuwt Stevens en hij kent Church inmiddels goed genoeg om te weten dat dat zijn bedoeling niet is.

I may be quite wrong about it, but my guess is that your interest in an American Mesures is simply your desire to live in your own world, even if you have to create it. The desire to achieve the thing that each number of Mesures is is your way of satisfying yourself; it is your way of writing music, or of painting, etc. ${ }^{25}$

In zijn brieven gaat Stevens in op de situatie van de eerder genoemde Amerikaanse tijdschriften die hij niet erg hoopgevend vindt en wijst hij Church op de onmogelijkheid op dit moment een uitwisseling van teksten met Europa tot stand te brengen. Het resultaat is dat er geen Amerikaanse voortzetting van Mesures komt en dat de aandacht van Church zich geleidelijk richt op een volgend project, The Henry Church Chair of Poetry. ${ }^{26}$

Het is niet direct duidelijk welke vorm dit project zou moeten aannemen en Church overlegt weer met Stevens. Deze geeft hem zijn ideeën over de effecten van scholarships en stelt hem op de hoogte van de mogelijkheden die 


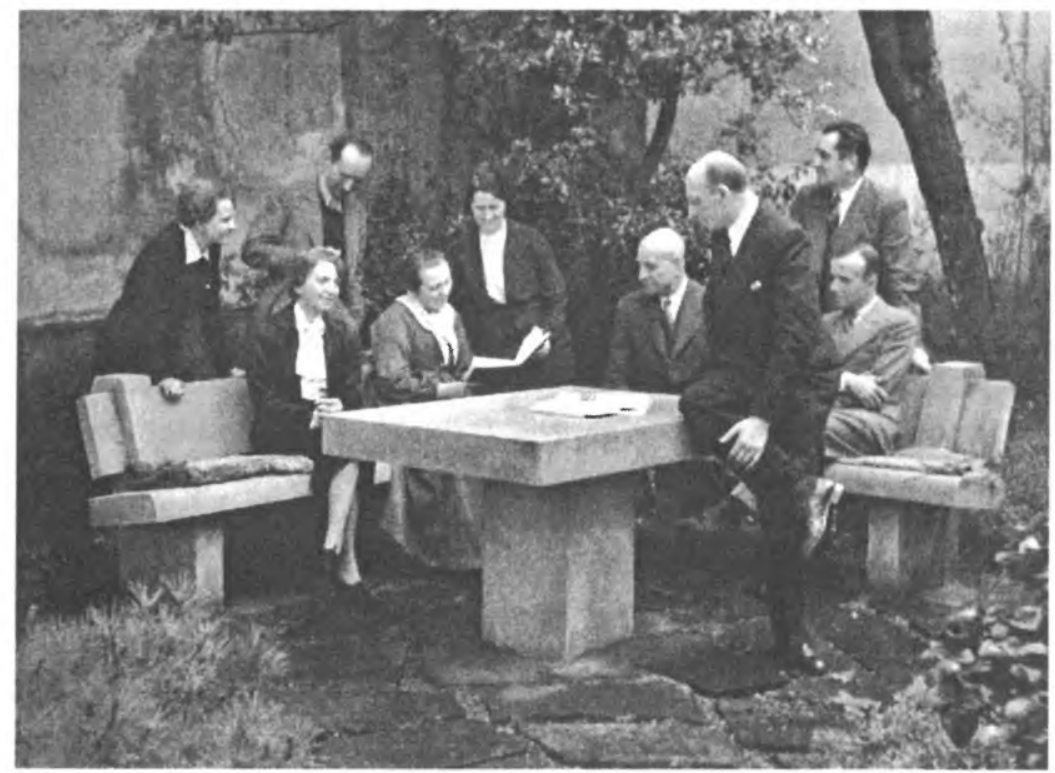

Redactievergadering Mesures in Ville d'Avray, 1937. V.l.n.r. Sylvia Beach, Barbara Church, Vladimir Nabokov (staand), Adrienne Monnier, Germaine Paulhan, Henry Chutch, Henri Michaux (staand bij de tafel), Jean Paulhan (staand), Michel Leiris (foto Gisèle Freund; zie ook noot 15)

al bestaan via het Guggenheim Fund en de Rhodes Trust. Voor exacte informatie verwijst hij Church naar Princeton University. Aan het eind van zijn brief van 28 mei 1940 wordt Stevens plotseling heel expliciet:

I should like you to establish The Henry Church Chair of Poetry at Harvard: that is to say, a chair for the study of the history of poetic thought and of the theory of poetry. Apparently, however, educators would sniff at such a thing, since it seems to be considered that universities do the Arts and Letters more harm than good. Still, such a chair with, say, Jean Paulhan as its first incumbent might turn the tables on the educators. ${ }^{27}$

Het plan om Paulhan en zijn vrouw naar de Verenigde Staten te laten komen speelt in Church' brieven vanaf de herfst van 1940. 'Voici, vous dites 
que la chaire de Harvard vous tenterait', schrijft Church op 11 oktober 1940 aan Paulhan. In het vervolg van de brief blijkt de penibele financiële situatie waarin de Amerikaanse universiteiten verkeren een hindernis te vormen. De instelling van een leerstoel (waarvan Stevens in zijn brieven blijft dromen ${ }^{28}$ ) is kennelijk niet te realiseren, nu gaat het om een lezingentoernee van Paulhan langs verschillende universiteiten, Princeton, Harvard, Columbia enzovoort. Church zal de kosten van de reis en het verblijf voor zijn rekening nemen. Een andere mogelijkheid is dat Paulhan een benoeming als 'instructor' krijgt, hetgeen inhoudt dat hij met een klein groepje studenten een Franse auteur, Proust bijvoorbeeld, leest. Hij zal dan wel Engels moeten leren om met de studenten te kunnen communiceren. Ook dit plan gaat niet door, maar de wens een project te financieren blijft. Het wordt een serie 'Mesureslectures', vier lezingen per jaar, die al in 1940 voor de eerste keer door Amerikaanse dichters, critici en filosofen aan Princeton University gehouden zullen worden. ${ }^{29}$

Het contact met Paulhan, dat eind 1940 is verbroken, wordt zo snel mogelijk na de oorlog hersteld. De eerste bewaarde brief is van 4 april 1945 . Uit de brieven die dan nog volgen tot Church' dood, twee jaar later, blijkt hoezeer hij zijn Amerikaanse contacten inmiddels heeft geconsolideerd: hij is 'adviser' van The Sewanee Review geworden en probeert met Paulhans hulp een uitwisseling tot stand te brengen tussen de Franse en Amerikaanse literatuur.

In 1945 overweegt Church 'un numéro spécial de Mesures' uit te brengen. Hij schrijft: 'Le numéro de la libération était ma première pensée, puis je me suis dit, c'est trop prétentieux et je n'ai rien libéré.' Een mogelijke voortzetting van Mesures komt in iedere brief aan Paulhan aan de orde. Dat het uiteindelijk niet lukt, moet, lijkt mij, worden geweten aan de situatie in Frankrijk direct na de oorlog en aan de slechte fysieke en psychische toestand waarin èn Church èn Paulhan verkeren. Het laatste nummer van Mesures wordt de 'Hommage à Henry Church' die Paulhan in 1948 met grote zorg samenstelt. ${ }^{30}$

BALANS

Het zijn de herinnering aan Commerce en de imitatie van Commerce die Mesures parten spelen, zo analyseert Roger Caillois in zijn eerder geciteerde brief aan 
Paulhan de situatie van het tijdschrift in 1937. Het is opmerkelijk dat wat geldt in 1937 (en Caillois is zeker niet de enige die zo denkt) is blijven gelden tot nu toe. Als Mesures al wordt genoemd, dan toch altijd in een adem met het eerdere tijdschrift. Helemaal onterecht is dit niet, want de punten van overeenkomst tussen beide tijdschriften zijn talrijk: een Amerikaanse mecenas, een redactiecomité met Paulhan, Groethuysen en Ungaretti, geen literaire politiek en een interessante vermenging van oude en nieuwe, Franse en niet-Franse, Europese en niet-Europese teksten. Maar ook al was het model dan dat van Commerce, de inhoud van Mesures verschilt natuurlijk om de simpele reden dat het blad andere teksten en andere auteurs publiceerde. Mesures zocht bovendien contact met de lezers en dat lijkt mij het grootste punt van onderscheid te zijn geweest.

In plaats van op grond van een gelijkenis tussen beide bladen een wat negatief oordeel over Mesures te vellen omdat het meer van hetzelfde presenteerde, is het ook mogelijk de overeenkomst positief te waarderen. Musil noemt in een brief aan Groethuysen uit 1938 de 'Zeitunbekummertheit' van Mesures en prijst daarmee impliciet de durf van Church een dergelijke onderneming te continueren in weerwil van de tijd waarin zij leven. Terwijl in Europa de oorlog uitbreekt, probeert Church in Amerika datgene voort te zetten wat hem zo zeer ter harte gaat. Zelf noemt hij het kwaliteit en onderstreept een aantal malen hoe belangrijk het is te vermijden dat het blad zich vastlegt op één poëticale lijn. In de schriftelijke discussie met Stevens lijkt deze laatste in staat geweest te zijn nader te preciseren waarom het Church (en hemzelf) nu eigenlijk ging: 'the status of poetry - the philosophy of poetry - poetry as a discipline, the abstraction and the theory' - dit alles uiteindelijk culminerend in 'an attempt to disclose the truth about poetry'. ${ }^{31}$ Maar dit alles wordt opgemerkt in verband met de lezingen, dus op een moment dat het tijdschrift al niet meer bestaat. Terwijl de inhoud en de status van Mesures worden geroemd vanwege hun 'Zeitunbekummertheit', laten de brieven nu juist zien hoe 'zeitgemäss' het tijdschrift ook was, om met een variatie te verwijzen naar de filosoof Nietzsche die Church las en herlas. $\mathrm{Pu}-$ bliceerde Mesures bij voorkeur teksten die niet aan een tijd gebonden waren, het internationale literaire netwerk dat Church en Paulhan rond hun tijdschrift formeerden was dat uiteraard wel. De bestudering van de contacten die de deelnemers aan dit netwerk onderling onderhielden, brengt dat dui- 
delijk aan het licht. Het is nu juist de spanning tussen tijdloosheid en tijdgebondenheid die Mesures extra kleur en lading geeft. Daarom verdient ook dit tijdschrift een eigen plaats in de literatuurgeschiedenis van het interbellum.

> SOPHIE LEVIE promoveerde in 1988 aan de UvA op een onderzoek naar het literaire tijdschrift Commerce. Van 1988 tot 2001 was zij als U H D Cultuurgeschiedenis van de twintigste eeuw verbonden aan de vakgroep Literatuurwetenschap van de Universiteit Utrecht. Sinds september zoor is zij hoogleraar Algemene Literatuurwetenschap en Algemene Cultuurwetenschappen aan de Radboud Universiteit Nijmegen. 
I. Een gedetailleerde beschrijving van de wijze warop Paulhan zijn functie bij de NRF vervulde is te vinden in Martyn Cornick, Intellectuals in History. The Nouvelle Revue Française under Jean Paulhann, 1925-1940. Amsterdam/Atlanta 1995. Recenter is Laurence Brisset, La NRF de Paulhan. Parijs 2003.

2. In de twee banden Choix de Lettres zijn brieven van Paulhan aan een groot aantal Franse schrijvers opgenomen (Jean Paulhan, Choix de Lettres I, 1917-1936: La littérature est une fête. Parijs 1986. Choix de Lettres II, 1937-1945: Traité des jours sombres. Parijs 1992.) Begin 1996 voltooide Claire Paulhan de inventaris van de brieven die nog niet zijn uitgegeven. Deze inventaris wordt, met een groot deel van het materiaal dat er in staat vermeld, bewaard op het Institut Mémoires d'Edition Contemporaine (IMEC) te Parijs. De staf van het IMEC heeft mij tijdens bezoeken aan de bibliotheek van het instituut in 1995 en 1996 alle medewerking verleend, daarvoor ben ik uiteraard zeer erkentelijk. De huidige stand van zaken rond de editie van Paulhans correspondentie is gedocumenteerd in de bibliografie van Brisset 2003, 428-432.

3. Correspondance Jean Paulhan - Giuseppe Ungaretti 1921-1968 (Cahiers Jean Paulhan 5). Edition établie par Jacqueline Paulhan, Luciano Rebay et Jean Charles Vegliante. Préface de Luciano Rebay. Parijs 1989. Het citaat komt uit brief 152 .

4. Zie Jean Paulhan, Choix de Lettres I, brief 262.

5. Zie Ibidem, brieven 267 en 285 , tevens brieven 179 en 180 in: Jean Paulhan - Francis Ponge, Correspondance I: 1923-1946. Edition critique annotée par Claire Boaretto. Parijs 1986.

6. Brieven 261 en 264 in Jean Paulhan, Choix de Lettres 1 .

7. Adrienne Monnier staat de redactie de eerste drie jaat bij als administratrice; de uitgever en boekhandelaar José Corti neemt de functie van haar over met ingang van nummer 1 in 1938. Zie over Monnier en Mesures: Adricnne Monnier et la Maison des Amis des Livres 1915-1951. Textes et documents réunies et présentés par Maurice Imbert et Raphaël Sorin. Parijs 1991.

8. De brieven van Henry Church aan Paulhan maken deel uit van het Fonds Paulhan (IMEC). Ik heb ze daar mogen inzien en citeer en parafraseer ze in dit artikel met toestemming van de staf van het IMEC. In het nummer van Mesures dat als hommage aan Church werd uitgebracht na diens dood in 1947 (Mesures: Hommage à Henry Church, 15 avril 1948) is een biografische noot opgenomen. Daaruit blijkt dat Church in 1901 de vs verliet om in München muziek te gaan studeren, na vier jaar naat Parijs verhuisde waar hij onder andere meewerkte aan La Phalange (opgericht in 1906), van 1917 tot 1920 in Genève chemie studeerde en in 1921 terugkeerde naar Frankrijk om zich in Ville d'Avray te vestigen. Deze informatie is overgenomen in deel II van de correspondentie Paulhan - Ponge, (Jean Paulhan - Francis 
Ponge, Correspondance II: 1946-1968. Edition critique annotée par Claire Boaretto. Parijs 1986). brief 39o, noot 1

9. Van de brieven die Henry Church aan Paulhan stuurde is nog niets gepubliceerd. Het materiaal is gedeeltelijk geotdend en bestaat uit verschillende dossiers met mappen waarin de brieven min of meer chronologisch gerangschikt zijn. Het materiaal beslaat de periode 1934 tot 1960 . In totaal zijn er circa 200 brieven en andere documenten - er is geen onderscheid gemaakt tussen de brieven van Henry Church en die van Barbara Church; dit verklaart het feit dat het materiaal na 1947 doorloopt. De brieven zijn deels met de hand geschreven, deels getypt - duidelijk wordt dat Barbara Church regelmatig de correspondentie van haar man verzorgde. De vele tikfouten, de grammaticale blunders en slordigheden van vooral Henry Church, die uiteraard geen native speaker was, zijn soms door hem met de hand gecorrigeerd. Veel vaker echter zag hij de fouten over het hoofd, herkende ze niet of vond ze niet belangrijk. Deze fouten zijn door mij niet overgenomen in de citaten om de tekst niet te belasten met een overmatig aantal keren 'sic'. Uit de brieven van Church wordt in dit artikel zonder verdere verwijzingen geciteerd: de definitieve ordening van het materiaal dient immers nog te geschieden. 10. Brisset 2003 wijdt een aantal bladzijden aan een vergelijking tussen Commerce en Mesures en de twee Amerikaanse mecenassen van deze Franse tijdschriften en herneemt daar dit idee. Zie over Commerce: Sophie Levie, Commerce 1924-1932, une revue internationale moderniste. Rome 1989.

11. Jean Paulhan - Francis Ponge, Correspondance l, brief 181 .

12. Brief 24 in: Correspondance Jean Paulhan Roger Caillois 1934-1967 (Cahiers Jean Paulhan 6). Edition établie et annotée par Odile Felgine et Claude-Pierre Perez avec le concours de Jacqueline Paulhan. Préface de Laurent Jenny. Parijs 1991.

13. Zie Sophie Levie, Commerce 1924-1932, 150, n.114; passim.

14. Over Michaux en Mesures is wat informatie te vinden in: Brigitte Ouvry-Vial, Henri Michaux. Qui êtes-vous? Lyon 1989. 15. Gisèle Freund, de Duits-Frans-Amerikaanse fotografe die zoveel prachtige schrijversportretten heeft gemaakt, was in 1937 aanwezig bij een vergadering van Mesures en maakte een serie foto's. Op één daarvan zitten en staan rond een tafel, beladen met papieren, boeken en nummers van Mesures, Michaux, Nabokov, Adrienne Monnier, Sylvia Beach, Germaine Paulhan (Paulhans vrouw), Leiris, Paulhan, Barbara Church en Church. Deze foto is afgedrukt in het boek van B. Ouvry-Vial (zie noot 14). Een andere foto uit dezelfde serie is te vinden in Adrienne Monnier et la Maison des Amis des Livres 1915-1951 (vermeld in noot 7 ). 16. Op 30 april 1936 nodigt Paulhan Ponge uit om, kennelijk voor de eerste keer, een van deze bijeenkomsten bij te wonen. Paulhan geeft aan dat Ponge de trein moet nemen 
op het Gare Saint-Lazare en dat de auto (van Church) hem vervolgens zal opwachten bij het station van Sèvres-Ville d'Avray. Zie Jean Paulhan - Francis Ponge, Correspondance l, brief 202.

17. Zie brieven 159 en 161 in Correspondance Jean Paulhan - Giuseppe Ungaretti.

18. Hoezeer Musil en zijn vrouw Martha voor, maar vooral na hun vertrek uit Oostenrijk in augustus 1938 waren aangewezen op de financiële en morele steun van personen en verschillende hulpcomités is bekend uit de brieven en dagboeken van Musil die zijn uitgegeven en geannoteerd door Adolf Frisé. De brieven aan Henry en Barbara Church die Musil en zijn vrouw schreven zijn, voorzover bewaard, daarin opgenomen. Church, die in het voorwoord bij de brieveneditie uitgebreid wordt genoemd als helper en mecenas, steunde de Musils vanaf 1938 maandelijks met 50 dollar. Het schrijnende verhaal van de initiatieven die de schrijver ondernam om zijn werk gepubliceerd te krijgen, zijn pogingen via allerlei contacten een permanent toevluchtsoord te vinden in Frankrijk of de Verenigde Staten en zijn constante geldgebrek is, in gecondenseerde vorm, in de brieven aan de Churches te lezen. Robert Musil, Briefe 1901-1942. Herausgegeben von Adolf Frisé. Reinbek bei Hamburg 1981. 19. Zie Sophie Levie, Commerce 1924-1932, 88, 216, passim.

20. Catherine Pozzi overleed eind 1934. In Mesures 3, 1935 werden vijf gedichten van haar opgenomen. Drie gedichten van Stefan
George werden in haar vertaling gepubliceerd in Mesures 1936, 2. Zie ook Catherine Pozzi, Journal 1913-1934. Préface de Lawrence Joseph. Edition établie et annotée par Claire Paulhan. Parijs 1987, 476, n.3.

21. Het tijdschrift Twice a Year. Semi-annual Journal of Literature, the Arts and Civil Liberties werd in 1938 opgericht door de Amerikaanse Dorothy Thompson. Tussen 1938 en 1948 verschenen in New York 17 nummers. Kraus Reprint bracht in 1967 een herdruk uit. 22. In de briefwisseling van Paulhan met Ungaretti, Ponge, Caillois en anderen is ook regelmatig sprake van een mogelijke voortzetting van Mesures, direct na de oorlog. 23. Zie de brieven 385 en 387 in Letters of Wallace Stevens. Selected and edited by Holly Stevens. New York 1966.

24. Letters of Wallace Stevens, brief 403.

25. Ibidem, brief 407.

26. Church heeft de Amerikaanse bladen in de jaren '40 overigens wel met flinke bedragen gesteund. Zie G.A.M. Janssens, The American Literary Review. A Critical History 19201950. Den Haag/Parijs 1968.

27. Letters of Wallace Stevens, brief 403.

28. In brief 413, gedateerd 15 oktober 1940, geeft Stevens Church raad over de verschillende manieren waarop hij de ideeën met betrekking tot de Poetry Chair in zijn testament kan opnemen. Hij waarschuwt Church dat doel en functie van de leerstoel zeer zorgvuldig beschreven zouden moeten worden voordat de plannen met de universiteiten worden besproken en geeft 
vervolgens in een memorandum zijn eigen opvattingen over het bestuderen van poëzie in een academische context. Hoezeer Stevens bezig blijft met het idee blijkt bijvoorbeeld uit de brieven 464,480 en 481 (van november ' 42 en van maart en april '43) aan Church en Jean Wahl.

29. Tussen de papieren van Church in het Fonds Paulhan bevindt zich ook een map brieven van Church aan Stevens uit de periode 1942-'47. Het betreft hier ongetwijfeld (een deel van?) de brieven die Stevens direct na het overlijden van Church aan Barbara Church heeft teruggegeven. Zie brief 605 in The Letters of Wallace Stevens. Uit dit materiaal komt ook het citaat waarin Church zijn me- ning over Musil geeft. In de correspondentie tussen Church en Stevens van eind 1940 tot 1944 wordt regelmatig op organisatorische en inhoudelijke kwesties betreffende de lezingen ingegaan. Church vtaagt Stevens om sprekers te suggereren en wil weten wat diens oordeel is over de namen die hij zelf heeft geselecteerd. In de eerste reeks spraken Philip Wheelwright, Cleanth Brooks, I.A. Richards en Stevens. Deze lezingen zijn gebundeld onder de titel The Language of Poetry, ed. Allen Tate, Princeton 1942.

30. In de Index de Mesures staan de auteurs van dit herinneringsnummer en hun bijdragen vermeld.

31. Letters of Wallace Stevens, brief 419. 